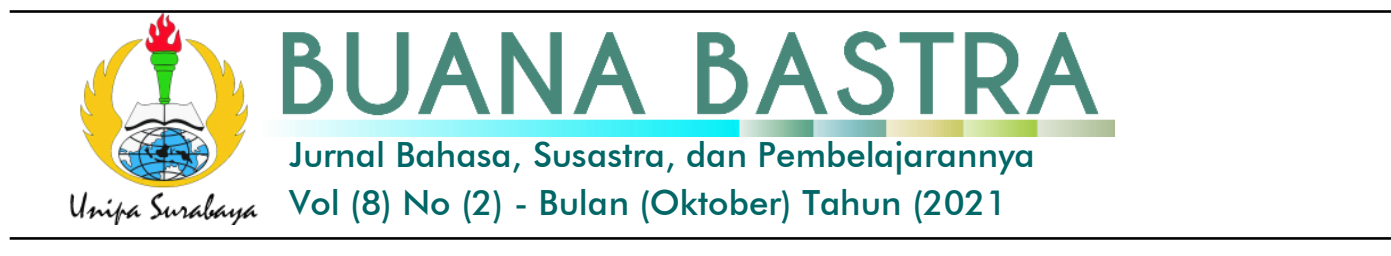

\title{
IDEOLOGI PERLAWANAN DALAM PUISI BULAN HANGUS DI JAKARTA KARYA SITI ZALEHA M. HASYIM
}

\author{
Indayani \\ Program Studi Pendidikan Bahasa Indonesia, Fakultas Ilmu Sosial dan Humaniora \\ Universitas PGRI Adi Buana Surabaya \\ indayani@unipasby.ac.id
}

\begin{abstract}
ABSTRAK: Penelitian ini bertujuan mengaji struktur ideologi yang diproduksi pada puisi dengan menggunakan teori materialisme historis Terry Eagleton. Dalam puisi Bulan Hangus di Jakarta ditemukan relasi antara konstituen internal dengan konstituen eksternal (teks) serta sejarah. Puisi ini merupakan kekalutan dan kerusuhan yang terjadi pada era orde baru dipimpin oleh Presiden Soeharto. Kerusuhan dan kekalutan terjadi karena masyarakat Indonesia berusaha menggulingkan Presiden Soeharto yang dianggap berlaku sewenang-wenang terhadap rakyat dan membatasi hak-hak rakyat. Metode penelitian yang digunakan adalah kualitatif deskriptif. Hasil penelitian ini adalah perlawanan rakyat terhadap kekuasaan rezim yang otoritarian dan ideologi teks yang terikat terhadap peristiwa yang terjadi pada era revolusi.
\end{abstract}

Kata kunci: ideologi perlawanan, puisi, dan materialisme historis

ABSTRACT: This study aims to examine the ideological structure produced in poetry using Terry Eagleton's theory of historical materialism. In the poem Bulan Hangus in Jakarta, the relationship between internal constituents and external constituents (text) and history is found. This poem represents the chaos and unrest that occurred during the New Order era led by President Suharto. The riots and chaos occurred because the Indonesian people were trying to overthrow President Soeharto, who was considered to be acting arbitrarily against the people and limiting the people's rights. The research method used is descriptive qualitative. The results of this study are the people's resistance to the authoritarian regime and the ideology of the text that is bound to events that occurred in the revolutionary era.

Keywords: resistance ideology, poetry, and historical materialism

\section{PENDAHULUAN}

Pengalaman sejarah pada era orde baru telah banyak memberikan pembelajaran kepada generasi penerus mengenai arti kebebasan sebagai fundamental yang membentuk pemikiran kritis masyarakat untuk turut berkontribusi dalam mengawal sistem pemerintahan. Masyarakat beranggapan 
kekuasaan pemerintah yang sewenang-wenang dalam mengendalikan aturan sehingga timbul gejolak perlawanan dari sebagian masyarakat yang menilai pemerintah telah melakukan tindakan penyelewengan dan penyimpangan guna melindungi kepentingan penguasa. Penyair Siti Zaleha M. Hasyim melihat fenomena revolusi yang terjadi melalui pengalaman indrawinya sehingga melahirkan puisi sebagai sebuah manifestasi kegundahan batin. Penyair melihat berbagai ketimpangan seperti halnya kemiskinan yang memburuk akibat krisis moneter, pembatasan hak bersuara atau kritik terhadap pemerintah dibatasi, tindakan represif aparat, dan penjarahan yang dilakukan masyarakat sebagai bentuk ketidakpuasan dan emosional atas kondisi yang terjadi.

Aminuddin (2009:134) mengatakan bahwa puisi adalah sebuah dunia dalam kata yang terkandung yang merupakan cerminan pengalaman, pengetahuan, dan perasaan penyair yang membentuk sebuah dunia di dalam puisi. Peristiwaperistiwa yang terjadi era revolusi terhadap orde baru tersebut merupakan jejaring relasi yang membentuk lahirnya puisi Bulan Hangus di jakarta. Kekuasaan pemerintah yang otoriter memengaruhi puisi tersebut untuk memproduksi ideologi dengan struktur kekuasaan sehingga adanya narasi politik yang dibalut dengan sisi humanisme. Penyair menanamkan ideologinya dalam puisi tersebut guna memberikan pesan tersirat kepada pembaca sebagai kritikan atas hegemoni pemerintah yang kalut dalam menggunakan sistem pemerintah. Puisi Siti Zaleha M. Hasyim merupakan representasi atas fenomena kelam bangsa Indonesia, masyarakat dan mahasiswa berbondong-bondong turun ke jalan guna menyuarakan ketidakadilan yang terjadi guna menggulingkan penguasa yang dianggap otoriter, puisi yang terdiri atas satu bait tersebut ditulis dengan menggunakan bahasa Melayu yang mudah dipahami oleh pembaca.

Puisi merupakan media komunikasi dan ekspresi bagi penyair dalam menggambarkan dunia nyata. Bilamana diselami secara dalam, terdapat perubahan masyarakat pada puisi tersebut yang tidak terlepas dari sarana ekonomi dan politik. Kesadaran rakyat termasuk penyair di dalamnya tidak dapat dilepaskan akibat kemunculan ideologi yang menjadi kekuatan untuk menggerakan sebuah api revolusi atau perlawanan. Komitmen rakyat untuk terlepas dari belenggu kemiskinan dan tekanan aturan-aturan yang justru menyudutkan serta merugikan masyarakat menjadi bahan pemantik munculnya kesadaran. Badawi (1998:15) mengatakan bahwa komitmen tersebut diharapkan mampu menjadikan karya sastra sebagai sebuah sarana yang mendekatkan masyarakat melalui pengambilan problematika masyarakat sebagai tema puisi dan menggunakan bahasa yang mudah dimengerti oleh masyarakat.

Penelitian ini menggunakan gagasan Terry Eagleton mengenai teori materialisme historis sehingga penelitian ini mengarah pada sejarah pergerakan produksi sastra puisi Bulan Hangus di Jakarta, dan struktur ideologi yang terkandung pada puisi tersebut. Puisi Bulan Hangus di Jakarta dapat dipandang sebagai sebuah produksi ideologi yang melalui sebuah mekanisme urutan seperti 
pandangan Endraswara (2011:229) mengatakan bahwa karya sastra tidak secara langsung menghadirkan sejarah atau fakta sosial, tetapi melalui proses mekanisme urutan, yaitu sejarah yang terdapat kondisi politik-sosial yang melahirkan ideologi yang kemudian muncul di dalam karya sastra dalam bentuk produksi ideologi.

Selaras dengan hal tersebut, rumusan masalah penelitian ini adalah bagaimana struktur ideologi pada puisi Bulan Hangus di Jakarta dan ajang kontestasi ideologi dalam formasi sosial? Pertanyaan tersebut mengarahkan penelitian pada konstruksi kekuasaan yang membentuk masyarakat dalam kehidupan sosial sesungguhnya. Selanjutnya, diinteraksikan dengan konstruksi pada karya sastra berupa bait-bait puisi guna menemukan motif ideologis yang terkandung. Bersumber dari gagasan Eagleton yang menganggap karya sastra terdapat ideologi yang diproduksi dari tatanan dan struktur luar teks sehingga menjadikan teks memproduksi ideologinya dari dialetika antara struktur luar dengan teks karya sastra. Praktik materialisme merupakan esensi realitas karya sastra yang menjadi sumber dan menguraikan partikulasi skema historis struktur teks menjadi mekanisme. Materialisme historis Eagleton dikelompokkan pada post-althusserian sebagai kritik sastra Marxis. Dalam praktik sastra, pentingnya penekanan pemahaman pada sebuah proses produksi untuk mengubah materi dengan mempertimbangkan pada tradisi kesusastraan, konvensi sastra, dan jenis karya sastra yang dapat memengaruhi ideologi estetik, nilai, dan wacana.

Penelitian ini menggunakan pendekatan metode kualitatif deskriptif. Selain itu, objek materialnya merupakan puisi Bulan Hangus di Jakarta karya Siti Zaleha M. Hasyim yang terdapat pada buku Antologi Puisi Perempuan IndonesiaMalaysia. Pemaknaan terhadap bait-bait puisi Bulan Hangus di Jakarta karya Siti Zaleha M. Hasyim menggunakan kerangka teori Terry Eagleton. Berangkat dari teori Terry Eagleton menganggap bahwa teks sastra merupakan suatu produk interaksi dialektis dalam kritik sastra materialsitik yang meliputi (1) cara produksi umum (2) cara produksi sastra (3) ideologi umum (IU) (4) ideologi kepengarangan (IK) dan (5) ideologi estetik (IE). Cara produksi umum (CPU) merupakan kekuatan yang berada pada dimensi sosial yang diproduksi materil. Kekuatan yang terdapat pada CPU meliputi alat, bahan, rangkaian interaksi agen yang terlibat dan teknik produksi. Selanjutnya, cara produksi sastra (CPS) merupakan teks sastra yang menimpa sastra lisan yang terbentuk dari perjalanan diakronik agen secara historis. Pada corak produksi sastra terdapat adanya dominasi kesatuan kekuatan dengan hubungan sosial, yang produksinya berada pada formasi sosial. Penerapan tenaga-tenaga merupakan kekuatan produksi sastra yang teroganisasikan dalam hubungan produksi dan berkesinambungan dengan corak produksi umum.

Ideologi Umum (IU) merupakan ansambel ideologi yang dipengaruhi oleh formasi sosial pada corak produksi umum sehingga membentuk ideologi dominan. Berangkat dari dasar seperangkat wacana mengenai nilai, kepercayaan, dan representasi yang direalisasikan dengan perangkat materia sehingga 
mencerminkan adanya hubungan kondisi sosial dengan pengalaman individu agar dapat menjamin adanya kekeliruan yang telah berkontribusi pada proses reproduksi hubungan sosial. Hal tersebutlah yang akan memengaruhi ideologi estetik. Selanjutnya, ideologi kepengarangan (IK) yang merupakan sisipan seperangkat fitur sang penyair ke dalam teks. Hal tersebut dilakukan oleh berbagai faktor di antaranya; jenis kelamin, agama, kebangsaan, wilayah geografis, dan kelas sosial. Ideologi estetik (IE) merupakan subsektor sastra yang merupakan pemilihan gaya bahasa dan diksi penyair yang dilakukan penyair sebagai sebuah ekspresi perlawanan. Semua ideologi tersebut saling berkesinambungan secara timbal balik sehingga membentuk ideologi teks.

\section{HASIL PENELITIAN DAN PEMBAHASAN \\ CPU: Hegemoni Orde Baru}

Puisi merupakan bentuk ekspresi pengarangan yang merupakan representasi perlawanan estetik yang mengandung aspek materialistik yaitu cara produksi umum (CPU) dan cara produksi sastra (CPS) sebagai pemilihan genre yang digunakan untuk menyampaikan ide dan gagasan, selain itu aspek lainnya berkaitan dengan ideologi kepengrangan (IK) dan ideologi estetik yang merujuk pada pemilihan diksi, dan gaya bahasa yang digunakan oleh penyair sebagai media ekspresi perlawanannya. Puisi Bulan Hangus di Jakarta karya Siti Zaleha M. Hasyim menggambarkan mengenai kondisi reformasi yang dilakukan masyarakat guna menumbangkan kekuasaan rezim orde baru yang otoriter. Ada pun puisinya

Bulan Hangus di Jakarta

Siti Zaleha M. Hasyim

Bulan hangus di Jakarta

Orang-orang kecil

Terperangkap dalam sengsara

Mengutip rupiah yang pecah

Merangkak, mengoyak bumbung

Parlimen, melontar 200 juta suara

Bulan hangus di Jakarta

Langit terbelah dua

Dari runtuhan bangunan

Asap tebal bergulung melolong

Sejak DKA tiba, malam semakin hitam

Setelah bapa-bapa bersidang

Jakarta mengepung dendam

Orang-orang hanyut semakin jauh

Dicakar, mencakar, dicabar, mencabar 
Bulan hangus di Jakarta

Jangan kautanya

Siapa yan mula membakar

Selagi diri bergelar manusia

Luka benua, darahnya

Terpecik ke muka kita

Pedihnya turut sama dirasa.

Kuala Lumpur

18 Mei 1998

(Bertia Minggu, 7 Jun 1998)

Sesuai dengan tanggal terciptanya puisi yang tertera dalam puisi tersebut yaitu “(Bertia Minggu, 7 Jun 1998)". Kondisi Jakarta mengalami kerusahan akibat reformasi yang dilakukan oleh mahasiswa dan masyarakat pada tahun 1998. Masa orde baru merupakan tatanan kekuasaan yang dipegang oleh presiden Suharto. Presiden Suharto telah menjabat selama 32 tahun, menggantikan orde lama di bawah kepemimpinan Soekarno. Namun, di bawah rezim orde baru, masyarakat menganggap pemerintahan yang dijalankan penuh sikap otoriter. Ciri sikap otoriter yang dijalankan oleh pemerintahan tersebut antara lain (1) Militer memegang alih pemerintahan, (2) berkolaborasi dengan tekonorat sipil serta didukung oleh oligopolistik, (3) Penggunaan kekuasaan yang sewenang-wenang. Pada awal masa pemerintahannya, Presiden Suharto menggunakan prinsip ideologi pembangunan guna menciptakan segala bentuk kemajuan di berbagai bidang. Namun, seiring perkembangannya, rezim orde baru mulai melihatkan sikap otoriterismenya, yang ditandai dengan dwifungsi pada tubuh militer (ABRI) serta hanya mementingkan kelompok tertentu seperti partai golongan karya-yang menjadi penguasa kursi-kursi politik. Selain itu, terjadinya inflasi yang tinggi terhadap mata uang Indonesia sehingga menjadikan harga kebutuhan pokok mahal. Hal tersebut memperparah kemiskinan karena masyarakat kesulitan untuk mendapatkan kebutuhan pokok. Hal tersebut merupakan tampilan CPU pada puisi Bulan Hangus di Jakarta yang digambarkan melalui petikan puisi berikut.

Orang-orang kecil

Terperangkap dalam sengsara

Mengutip rupiah yang pecah

Merangkak, mengoyak bumbung

Parlimen, melontar 200 juta suara

Petikan puisi tersebut menggambarkan kondisi rakyat kecil yang mengalami kemiskinan akibat faktor pembiaran dan pengelolaan bidang ekonomi yang gagal dari pemerintah. Terjadinya inflasi terhadap mata uang sebagai representasi hegemoni oligopolistik serta dominasi partai Golkar yang memenangkan 
pemilihan umum sebanyak enam kali. Penyair secara tangkas mampu menggambarkan kondisi tersebut dengan balutan gaya bahasa hiperbola untuk menciptakan atmosfer kegundahan yang mendalam atas ketimpanganketimpangan terjadi pada era rezim orde baru. Petikan puisi di atas merupakan CPU yang diserap oleh penyair hegemoni kekuasaan orde baru yang mendorong penyair untuk membangun dimensi sosial yang menggambarkan betapa pengaruhnya kekuasaan pemerintah.

\section{CPS: Kesadaran Kolektif Penyair}

Pada produksi kepenulisan puisi, penyair melewati berbagai pengalaman proses yang memengaruhi bahan mentah. Hal tersebut meliputi sejarah, masalah sosial, dan perangkat lainnya yang telah melalui konvensi sastra sehingga hal tersebut merupakan serangkaian proses rumit sang penyair dan menjadikan karya sastra bukan lagi sebagai proses ekspresi bahasa semata. Pembatasan hal berekspresi dan suara untuk media massa dan pemberatasan buku-buku yang dianggap mengkritik pemerintah memaksa tokoh intelektual mengelurkan kritikan. Selaras dengan hal tersebut, penyair Siti Zaleha M. hasyim yang latar belakangnya merupakan seorang redaktur dan penyiar di Radio Televisyen Malaysia (RTM) terdorong untuk melakukan sejumlah gerakan sebagai wujud kesadaran kolektifnya dengan menciptakan puisi ini sebagai bentuk kritikan penguasa yang membatasi pers. Serangkaian fenomena tersebut membentuk CPS yang menjadi realisme sosial di Indonesia.

\section{IU: Rezim Otoriterialisme-Kapitalisme dan Ideologi Perlawanan}

Kemunculan ideologi umum sebagai bentuk dominasi atas ideologi sosial lainnya menjadi sebuah cerminan subjek atas kondisi sosial. Hal tersebutlah yang nantinya dapat menjadikan relasi sosial pada masyarakat. Ideologi umum pada era orde baru yakni reformasi pembangunan, tetapi tersebut menjadi paradoks karena negara lebih menunjukkan sisi otoriter pada masyarakat dan kapitalistik pada aspek ekonomi. Pemerintah menggunakan peran ABRI sebagai upaya untuk melenggangkan manuvernya atas segala bidang yang dikuasai dengan menekan masyarakat menggunakan aturan dan tindakan reprsesif aparat yang disertai dengan teror. Perthatikan petikan puisi berikut.

Setelah bapa-bapa bersidang

Jakarta mengepung dendam

Orang-orang hanyut semakin jauh

Dicakar, mencakar, dicabar, mencabar 
Petikan puisi tersebut terdapat adanya gambaran sikap otoriter yang direpresentasikan oleh larik "setelah bapa- bapa bersidang". Pemerintah melegalkan segala cara termasuk menciptakan hukum-hukum yang dapat menyudutkan dan mempersempit gerak rakyat dengan dalih membahayakan pemerintah. Selain itu, adanya ideologi kaptialisme yang lahir dari hagemoni pemerintah yang timbul adanya oligarisme. Hal tersebut direpresentsikan pada larik kedua dan ketiga yaitu "orang-orang kecil, terperangkap dalam sengsara. Sikap otoriterisme dan kapitalisme pemerintah melahirkan ideologi lain dari kesadaran masyarakat yaitu ideologi perlawanan yang direpresentasikan melalui larik "orang-orang hanyut semakin jauh, dicakar, mencakar, dicabar, mencabar" hal tersebut merupakan gambaran mengenai kontestasi ideologi pada dimensi sosial antara pemerintahan yang otoriter dan masyarakat yang melawan, direpresentasikan melalui larik "Jakarta mengepung dendam”.

\section{IK: Humanistik pada Kepenyairan}

Pengalaman yang terjadi pada diri penyair dapat dikaitkan sebagai ideologi kepengarangan karena karya sastra merupakan bentuk ideologi. Proses terbentuknya ideologi kepengarangan Siti Zaleha M. Hasyim berangkat dari ideologi umum yang telah terformasi sosial sehingga terkumpul, menjadikan penyair tersebut harus menerima kondisi historis yang membentuk pemikiran kolektivitas yang direpresentasikan melalui puisinya. Penyair mengelolah dan mengkonvensi ideologi umum menjadi serangkaian teks yang memiliki ideologi namun tidak dapat dipadankan dengan ideologi kepengarangan Siti Zaleha. M. Hasyim.

Ideologi kepengarangan Siti Zaleha M. Hasyim dapat ditelisik melalui biografinya atau perjalanan hidupnya. Siti Zaleha M. Hasyim lahir pada tanggal 6 November 1953 di Taiping Perak, Malaysia. Siti Zaleha merupakan penyair yang memulai kariernya sebagai Penolong Penerbit di Bahagian Hiburan, Radio Televisyen Malaysia (RTM). Beliau memeroleh gelar sebagai penyiar (sebaran Am) di Universitas Teknologi Mara (UiTM) serta ijazah sarjana (komunikasi) di Universitas of Leeds, United Kingdom. Siti Zaleha telah banyak menulis berbagai genre karya sastra seperti cepren, puisi, novel, pantun, syair dan lirik yang telah dimuat di berbagai media masa. Seperti halnya karya beliau Kapal Kertas dan Lautan Api yang merekam pandangan penyair terhadap kemanusiaan serta kehidupaan sebagai jalan puitiknya dalam menghasilkan bahasa-bahasa puitis.

Perhatiannya kepada kehidupan yang dibalut dengan sisi kemanusiaan menjadikan karya-karya Siti Zaiton M. Hasyim lebih menampilkan aspek humanistik. Melalui puisi Bulan Hangus di Jakarta, penyair menampilkan kepada pembaca mengenai kesedihan batinnya melihat realitas sosial semasa reformasi tersebut, nampak kegundahan batin terselip pada bait puisinya yang mengedepankan persoalan kemanusiaan yang muncul akibat fenomena kerusuhan 
adanya pembakaran, penindasa, penjarahan, dan tindakan represif aparat dalam mengawal jalannya demo para mahasiswa mampu dikonvensikan menjadi puisi.

\section{IE: Kritikan melalui Kegelisahan Batin Penyair}

Penyair secara gamblang menggambarkan kondisi yang terjadi di Jakarta tanpa takut terjelembab dalam penertiban rezim orde baru yang menguasai corak produksi sastra di Indonesia karena berdasarkan letak geografisnya, penyair berada di Malaysia, tepatnya di Kuala Lumpur sehingga gaya bahasa dan penulisan diksi penyair secara leluasa normatif disuguhkannya. Hal tersebut dapat dilihat melalui petikan puisi di bawah ini.

Siapa yan mula membakar

Selagi diri bergelar manusia

Luka benua, darahnya

Terpecik ke muka kita

Pedihnya turut sama dirasa

Pada petikan puisi tersebut merupakan gambaran mengenai situasi yang terjadi pada kota Jakarta. "Siapa yang mula membakar" merupakan representasi dari ajang kontestasi ideologi pemerintah dengan masyarakat. Nampak secara leluasa penyair menggunakan gaya bahasa hiperbola untuk menciptakan efek mencekam kepada pembacanya. Selain itu juga penyair membubuhkan kegelisahannya pada larik "Luka benua, darahnya, terpecik ke muka kita, pedihnya turut sama dirasa" yang merepresentasikan sisi humanistik penyair sebagai bentuk keperhatinan atas krisis kemanusiaan yang terjadi.

Pada reformasi 1998 terjadinya kerusuhan di kota Jakarta karena sebagai ibu kota Indonesia sehingga menjadi pusat fokus masyarakat dalam mengaplikasikan demokrasi guna menumbangkan kepemimpinan yang otoriterisme. Peristiwaperstiwa yang terjadi pada tahun 1998 di antara lain (1) Hilangnya para aktivis, (2) tragedi Trisakti dan Semanggi, (3) Lengsernya Presiden Soeharto (4) kerusuhan, penjarahan, dan diskriminasi etnis Tionghioa. Maka dari itu, penyair menggunakan judul Bulan Hangus di Jakarta sebagai simbol reformasi dan kerusuhan yang terjadi di Jakarta. Bulan merupakan simbol impian dan anganangan baru sedangkan Hangus merupakan representasi kekalutan dan kerusuhan pada situasi reformasi. Secara nontekstual, dapat dimaknai sebagai sebuah perjalanan dan perjuangan yang harus ditempuh bangsa untuk mewujudkan impian dan angan-angan. Melalui ideologi kepengarangannya yaitu humanisme, penyair mencoba menyadarkan dan memberikan kritik atas kontestasi ideologi pemerintah yang otoriterisme dan ideologi perlawanan pada masyarakat. Aspek kemanusiaan merupakan hal yang harus dijunjung tinggi sebagai bagian hak asasi manusia. 


\section{SIMPULAN}

Puisi Bulan Hangus di Jakarta karya Siti Zaleha. M. Hasyim mampu menyuguhkan mengenai transformasi realitas sosial ke dalam bentuk karya sastra yang telah melalui pengolahan konstituen-konstituen eksternal. Penyair secara tangkas mampu menangkap relitas sejarah yang terlahir untuk memberikan warna corak dan produksi ideologi yang memiliki relasi pada bait-bait puisi.

Konstituen-konsituen eksternal menunjukkan produksi ideologi yang dilakukan oleh penguasa. Ideologi yang dilahirkan oleh penguasa orde baru adalah otoriterisme dan kapitalisme yang menciptakan masyarakat kelas bawah pada dimensi sosial. Maka untuk dapat keluar jelembab ideologi pemerintah, dengan kesadaran kolektif masyarakat melahirkan ideologi perlawanan yang beresistensi dalam dimensi sosial. Adanya kontrakdisi di antara dua ideologi tersebut menciptakan konsistensi ideologi antara pemerintah dan masyarakat.

Melalui puisi Bulan Hangus di Jakarta, Siti Zaleha hadir dengan nilai-nilai kemanusiaan yang merupakan hasil produksi ideologi umum dalam bentuk formula yang telah melalui konvensi sastra. Ideologi kepengarangan lahir untuk melawan produksi otoriterisme dan kapitalisme dengan mekanisme kontrol terhadap kebebasan bersuara pada media masa dan ketidakadilan pada masyarakat. Penyair berusaha menyadarkan pembacanya dengan kontruksi ideologi mengenai struktur dan tatanan yang timbul.

\section{DAFTAR RUJUKAN}

Alfian Muhammad. 2019. Materialisme Historis dalam Noel Ronggeng Dukuh Paruk. Yogyakarta: Universitas Gadjah Mada. https://www.researchgate.net/publication/3341533618.com.

Aminudin. 2009. Pengantar Apresiasi Karya Sastra. Bandung: Sinar Baru Algensindo.

Badawi, M.M. 1998. A Short History of Modern Arabic literature. Oxford: Cleredon Press.

Damono, Sapardi Djoko, dkk. 2014. Kumpulan Puisi Indonesia-Malaysia. Jakarta: Yayasan Pustaka Obor Indonesia.

Eagleton, T. 1978. Criticism and Ideology: A study in Marxist Literary Theory. London: Verso.

Faruk. 2015. Pengantar Sosiologi Sastra: dari Strukturalise sampai PostModernisme. Yogyakarta: Pustaka Belajar.

Purnamawati Zulfa, dkk. 2019. Ideologi Perlawanan dalam Antologi Puisi Fi Tariqi Al-Fajri Karya Abdullah Al-Baradduni. Jurnal Penelitian Sastra. https://jurnal.ugm.ac.id/poetika/article/view/44452.

Teeuw. A. 1984. Sastra dan Ilmu Sastra. Bandung: Dunia Pustaka Jaya.

Wellek, Rene, dkk. 2016. Teori Kesusastraan. Jakarta: Gramedia Pustaka Umum. 